Wiraraja Medika : Jurnal Kesehatan
https://www.ejournalwiraraja.com/index.php/FIK
2088-415x (Print) |2685-9998 (online)

\title{
Dukungan Keluarga Pada Orang Dengan Gangguan Jiwa di masa Pandemi Covid-19
}

Eko Mulyadi ${ }^{1}$, Yulia Wardita ${ }^{2}$,Hadina Eka Camalia ${ }^{3}$, Abd Wahid ${ }^{4}$, Dwi Rahayu Wulandari ${ }^{5}$

1,2,3,4,5 Fakultas Ilmu Kesehatan Universitas Wiraraja

eko.mulyadi@wiraraja.ac.id*

*Corresponding Auhtor

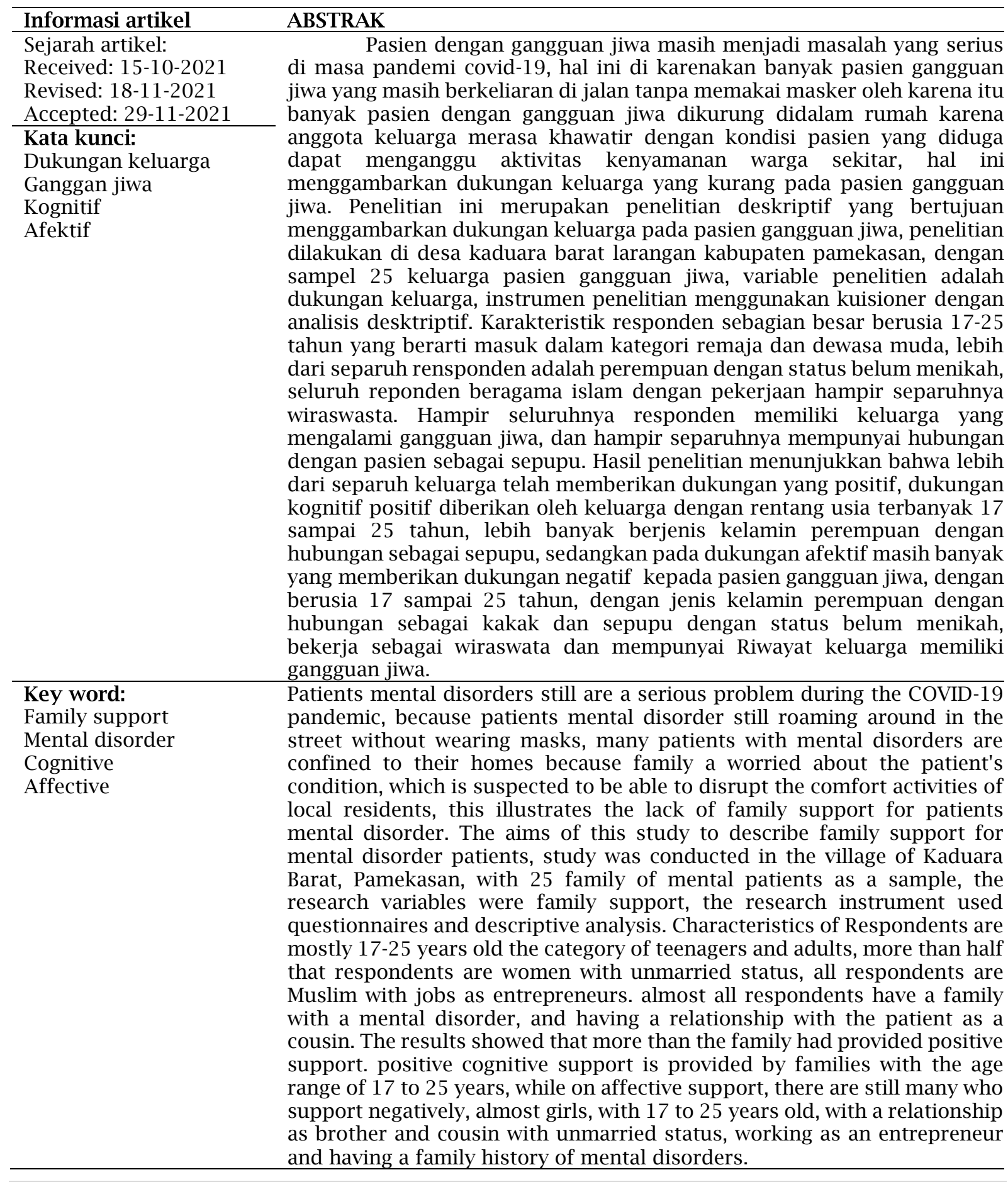




\section{PENDAHULUAN}

COVID-19, merupakan penyakit biomedis dengan implikasi kesehatan fisik dan mental yang serius. sebagai pandemi yang menyebar dengan cepat. Memperluas dampak psikologis karena melanda hampir seluruh negara (Suprayitno et al., 2020). Ditambah lagi kerugian ekonomi karena kehilangan pekerjaan yang merugikan secara bersamaan. Morbiditas psikologis yang sudah ada sebelumnya, seperti tidak adanya dukungan keluarga dan pengasuh selama krisis, keterbatasan mereka untuk mengikuti aturan dan peraturan keselamatan pribadi selama krisis COVID 19, pengucilan sosial, dan ketidakmampuan untuk mengakses layanan psikiatri secara tepat waktu semuanya menimbulkan tekanan psikologis. (Choudhari, 2020). Dukungan keluarga merupakan sikap, Tindakan dan penerimaan keluarga pada anggota keluarga yang sakit, dukungan dapat berupa pertolongan dan bantuan jika diperlukan, Berbeda dengan pasien yang menderita sakit fisik, pasien dengan gangguan jiwa kurang mendapat dukungan keluarga. Bahkan masih banyak keluarga yang melakukan pengekangan dengan Tindakan pasung (Yusuf et al., 2017)

$$
\text { Dukungan keluarga dapat }
$$

dipengaruhi karena pengetahuan dari keluarga tentang gangguan jiwa, hasil penelitian fenomenologi di wilayah kerja Puskesmas Sebakung Jaya dengan Jumlah informan 6 orang menyebutkan bahwa keluarga tidak mengetahui gejala dari gangguan jiwa,keluarga juga tidak tahu pengertian dari gangguan jiwa, bahkan sebagian penyebab gangguan jiwa karena permasalahan di keluarga itu sendiri (Rosdiana, 2018) sebaliknya, dukungan keluarga yang baik dapat mengurangi tingkat kecemasan pasien juga pada lansia yang menghadapi pensiun (Syafitri, 2015). Dukungan keluarga dapat meningkatkan kemandirian pasien gangguan jiwa, kemandirian dapat tercapai secara maksimal dengan adanya dukungan yang baik dari keluarga sehingga tidak tergantung pada keluarga.(Khamida et al., 2018).

Pasien dengan gangguan jiwa masih menjadi masalah yang serius di msa pandemic covid 19 . Pasalnya masih banyak pasien gangguan jiwa yang masih berkeliaran dijalan-jalan raya ataupun jalanjalan kecil di sekitar tanpa masker. Tidak sedikit pula dari mereka yang dikurung didalam rumah karena anggota keluarga merasa khawatir dengan kondisi pasien yang diduga dapat menganggu aktivitas kenyamanan warga sekitar. Hal ini menggambarkan dukungan keluarga yang kurang pada tempat penelitian.

Beberapa dari keluarga pasien mengatakan bahwa keluarga merasa pasrah akan pengobatan yang diberikan oleh pihak rumah sakit. Sehingga keluarga pasien menganggap tidak perlu untuk mendampingi pasien untuk pergi berobat ataupun pergi kontrol. Berdasarkan studi pendahuluan yang telah dilakukan, fonemena yang didapatkan bahwa banyak pasien yang kembali berobat karena penyakitnya kambuh karena tidak diperhatikan oleh keluarga dalam pengobatan selama dirumah, sebagian dari pasien yang datang berobat juga tidak ditemani oleh keluarga melainkan datang sendiri. Penelitian ini bertujuan untuk mengetahui dukungan keluarga pada pasien gangguan jiwa masa pandemic covid-19 di Desa Kaduara Barat Kecamatan Larangan Kabupaten Pamekasan.

\section{METODE PENELITIAN}

Desai Penelitian ini adalah deskriptif kualitatif, populasi yang di gunakan yaitu keluarga pasien yang menderita gangguan jiwa halusinasi, jumlah populasi dalam penelitian ini adalah 25 orang, sampel penelitian ini adalah anggota keluarga di Desa Kaduara Barat Kecamatan Larangan Kabupaten Pamekasan yang memiliki anggota keluarga dengan gangguan jiwa halusinasi yang sesuai dengan kriteria, adapun total jumlah keseluruhan sample yang terdapat didesa kaduara barat sebanyak 25, penelitian ini di ambil dengan menggunakan teknik purposive sampling, sampel penelitian ini di ambil dari anggota keluarga yang memiliki anggota keluarga dengan skizofrenia, penelitian ini menggunakan instrumen kuesioner close ended question menggunakan Likert Scale memuat 15 item pertanyaan, penelitian ini bertujuan untuk menggambarkan dukungan keluarga pada pasien gangguan jiwa, penelitian dilakukan di Desa Kaduara Barat Larangan Kabupaten Pamekasan, variable penelitien adalah dukungan keluarga. 
HASIL DAN PEMBAHASAN

1. Karakteristik responden

Tabel 1. Karakteristik responden

\begin{tabular}{|c|c|c|c|}
\hline No & Umur & $\mathbf{F}$ & $\%$ \\
\hline 1 & 12-16 tahun & 3 & $12 \%$ \\
\hline 2 & $17-25$ tahun & 9 & $36 \%$ \\
\hline 3 & 26-35 tahun & 8 & $32 \%$ \\
\hline 4 & 36-45 tahun & 3 & $12 \%$ \\
\hline \multirow[t]{2}{*}{5} & 46-55 tahun & 2 & $8 \%$ \\
\hline & Jenis Kelamin & $\mathbf{F}$ & $\%$ \\
\hline 1 & Laki-laki & 8 & $32 \%$ \\
\hline \multirow[t]{2}{*}{2} & Perempuan & 17 & $68 \%$ \\
\hline & Status & $\mathbf{F}$ & $\%$ \\
\hline 1 & Menikah & 14 & $56 \%$ \\
\hline \multirow[t]{2}{*}{2} & Belum menikah & 11 & $44 \%$ \\
\hline & Agama & $\mathbf{F}$ & $\%$ \\
\hline \multirow[t]{2}{*}{1} & Islam & 25 & $100 \%$ \\
\hline & Pekerjaan & $\mathbf{F}$ & $\%$ \\
\hline 1 & Tidak bekerja & 9 & $36 \%$ \\
\hline 2 & PNS & 6 & $24 \%$ \\
\hline 3 & Wiraswasta & 10 & $40 \%$ \\
\hline \multicolumn{2}{|c|}{$\begin{array}{l}\text { Keluarga Menderita } \\
\text { Gangguan Jiwa }\end{array}$} & $\mathbf{F}$ & $\%$ \\
\hline 1 & Ada & 20 & $80 \%$ \\
\hline 2 & Tidak & 5 & $20 \%$ \\
\hline \multicolumn{2}{|c|}{ Status di keluarga } & $\mathbf{F}$ & $\%$ \\
\hline 1 & Ayah & 2 & $8 \%$ \\
\hline 2 & Ibu & 1 & $4 \%$ \\
\hline 3 & Kakak & 9 & $36 \%$ \\
\hline 4 & Adek & 3 & $12 \%$ \\
\hline 5 & Lain-lain & 10 & $40 \%$ \\
\hline Total & & 25 & $100 \%$ \\
\hline
\end{tabular}

Dari tabel diatas tampak yang paling responden terbanyak berumur 17 - 25 tahun yang berarti masuk dalam kategori remaja dan dewasa muda, pada masa ini responden masuk usia produktif, lebih dari separuhnya responden adalah perempuan dengan status belum menikah, seluruh reponden beragama islam dengan pekerjaan hampir separuhnya wiraswasta. Hampir seluruhnya responden memiliki keluarga yang mengalami gangguan jiwa, dan hampir separuhnya responden mempunyuai hubungan dengan pasien sebagai sepupu.

\section{Dukungan Keluarga}

Tabel 2. Dukungan Keluarga

\begin{tabular}{ccc}
$\begin{array}{c}\text { Dukungan } \\
\text { Kognitif }\end{array}$ & F & (\%) \\
\hline Positif & 15 & $60 \%$ \\
\hline Negatif & 10 & $40 \%$ \\
\hline
\end{tabular}

\begin{tabular}{ccc}
\hline $\begin{array}{c}\text { Dukungan } \\
\text { Afektif }\end{array}$ & F & \% \\
\hline Positif & 13 & $52 \%$ \\
\hline Negatif & 12 & $48 \%$ \\
\hline Total & 25 & $100 \%$ \\
\hline
\end{tabular}

Dari tabel diatas tampak bahwa lebih dari separuhnya keluarga telah memberikan dukungan kognitif dan afektif yang positif. Penelitian menunjukkan bahwa dukungan keluarga secara signifikan terkait dengan kemarahan yang lebih rendah, depresi, kecemasan, dan PTSD. Dan dapat meningkatkan resilience dalam menghadapi kondisi yg penuh stress. (Vest et al., 2017)

Banyak pasien gangguan jiwa yang dianggap menjadi aib bagi keluarga besar, sehingga semakin sedikit anggota keluarga yang memberikan dukungan, mungkin hanya keluarga inti yang memberikan dukungan, atau anggota keluarga yang tinggal serumah, dukungan keluarga untuk pasien gangguan jiwa terutama yang terlantar merupakan hal yang penting dan signifikan dalam perawatan (Sanchaya et al., 2018).

Dukungan sosial dari keluarga teman sebaya dan lainnya dapat mengurangi resiko depresi atau gangguan jiwa lainnya (Sierau et al., 2019) pasien dengan gangguan jiwa dan tidak mendapat dukungan keluarga mendapatkan beban ganda, karena selain tidak mendapat dukungan mereka dikucilkan (Karmila et al., 2017).

Dukungan keluarga dan sosial saat ini mulai berkembang bahkan di tingkat internasional (Gani, 2019), salah satunya dukungan untuk gangguan jiwa, dukungan dapat berupa dukungan yang tidak disengaja (intentional support), mereka hanya berniat menemani dan tidak terorganisir dengan baik, biasanya mereka adalah penyintas yang kemudian merasa iba karena pernah mengalami gangguan jiwa, yang kedua adalah dukungan yang terintegrasi dan resmi, pada kelompok ini biasanya diberikan lebih professional dan resmi, namun dua bentuk dukungan tersebut tetap penting untuk pasien gangguan jiwa (Shalaby \& Agyapong, 2020).

\section{Dukungan Kognitif}

Tabel 3. Dukungan kognitif

\begin{tabular}{ccccccc}
\hline $\begin{array}{c}\text { Umur } \\
\text { (tahun) }\end{array}$ & \multicolumn{2}{c}{ Dukungan keluarga kognitif } & \multicolumn{3}{c}{ Total } \\
\cline { 2 - 8 } & Positif & Negatif & & & \\
\hline $12-16$ & f & \% & f & \% & f & \% \\
\hline $17-25$ & 2 & $8 \%$ & 1 & $4 \%$ & 3 & $12 \%$ \\
\hline $26-35$ & 6 & $24 \%$ & 3 & $12 \%$ & 9 & $36 \%$ \\
\hline
\end{tabular}




\begin{tabular}{|c|c|c|c|c|c|c|}
\hline $36-45$ & 2 & $8 \%$ & 1 & $4 \%$ & 3 & $12 \%$ \\
\hline $46-55$ & 1 & $4 \%$ & 1 & $4 \%$ & 2 & $8 \%$ \\
\hline Jenis kelamin & Positif & \multicolumn{3}{|c|}{ Negatif } & \multicolumn{2}{|c|}{ Total } \\
\hline & f & $\%$ & f & $\%$ & f & $\%$ \\
\hline Laki-laki & 5 & $20 \%$ & 3 & $12 \%$ & 8 & $32 \%$ \\
\hline Perempuan & 10 & $40 \%$ & 7 & $28 \%$ & 17 & $68 \%$ \\
\hline Total & 15 & $60 \%$ & 10 & $40 \%$ & 25 & $100 \%$ \\
\hline Status di keluarga & Positif & \multicolumn{3}{|c|}{ Negatif } & \multicolumn{2}{|c|}{ Total } \\
\hline & f & $\%$ & f & $\%$ & f & $\%$ \\
\hline Ayah & 2 & $8 \%$ & 0 & $0 \%$ & 2 & $8 \%$ \\
\hline Ibu & 0 & $0 \%$ & 1 & $4 \%$ & 1 & $4 \%$ \\
\hline Kakak & 3 & $12 \%$ & 6 & $24 \%$ & 9 & $36 \%$ \\
\hline Adik & 2 & $8 \%$ & 1 & $4 \%$ & 3 & $12 \%$ \\
\hline $\begin{array}{l}\text { Lain-lain (sepupu } \\
\text { tinggal } 1 \text { rumah) }\end{array}$ & 8 & $32 \%$ & 2 & $8 \%$ & 10 & $40 \%$ \\
\hline Total & 15 & $60 \%$ & 10 & $40 \%$ & 25 & $100 \%$ \\
\hline \multirow{2}{*}{ Status } & Positif & \multicolumn{3}{|c|}{ Negatif } & \multicolumn{2}{|c|}{ Total } \\
\hline & f & $\%$ & f & $\%$ & f & $\%$ \\
\hline Menikah & 6 & $24 \%$ & 8 & $32 \%$ & 14 & $56 \%$ \\
\hline Belum menikah & 9 & $36 \%$ & 2 & $8 \%$ & 11 & $44 \%$ \\
\hline Total & 15 & $60 \%$ & 10 & $40 \%$ & 25 & $100 \%$ \\
\hline \multirow[t]{2}{*}{ Pekerjaan } & Positif & \multicolumn{3}{|c|}{ Negatif } & \multicolumn{2}{|c|}{ Total } \\
\hline & f & $\%$ & f & $\%$ & f & $\%$ \\
\hline Tidak bekerja & 5 & $20 \%$ & 4 & $16 \%$ & 9 & $36 \%$ \\
\hline PNS & 5 & $20 \%$ & 1 & $4 \%$ & 6 & $24 \%$ \\
\hline Wiraswasta & 5 & $20 \%$ & 5 & $20 \%$ & 10 & $40 \%$ \\
\hline Total & 15 & $60 \%$ & 10 & $40 \%$ & 25 & $100 \%$ \\
\hline \multirow[t]{2}{*}{ Keturunan } & Positif & & Negatif & \multicolumn{3}{|c|}{ Total } \\
\hline & f & $\%$ & f & $\%$ & f & $\%$ \\
\hline Ada & 12 & $48 \%$ & 8 & $32 \%$ & 20 & $80 \%$ \\
\hline Tidak & 3 & $12 \%$ & 2 & $8 \%$ & 5 & $29 \%$ \\
\hline Total & 15 & $60 \%$ & 10 & $40 \%$ & 25 & $100 \%$ \\
\hline
\end{tabular}

Dari tabel diatas dapat dilihat bahwa lebih dari separuhnya yang memberikan dukungan kognitif positif kepada pasien gangguan jiwa berusia 17 sampai 25 tahun, dengan jenis kelamin perempuan dengan hubungan sebagai sepupu, status belum menikah, bekerja sebagai wiraswata dan mempunyai Riwayat keluarga memiliki gangguan jiwa. Dukungan kognitif keluarga seperti mengajarkan kepada penderita untuk menyibukkan diri seperti melakukan hoby, melatih penderita untuk bercakapcakap dan berinteraksi, membantu cara mengatasi gejala gangguan jiwa seperti cara mengatasi halusinasi dengan menghardik, membimbing penderita agar tetap menjaga kondisi kesehatan, mengamati perilaku penderita ketika terdapat kemajuan dalam perawatan diri. Dukungan keluarga seperti pendampingan, dukungan emosional, dukungan instrumental, dukungan kelompok atau persahabatan, dan dukungan informasi dapat meningkatkan kemandirian, keterampilan sosial, aktivitas dan emosi, sedangkan pengaruh terhadap keluarga, antara lain pekerjaan, emosi dan sosial. juga berperan langsung dalam proses pemulihan orang dengan gangguan jiwa.

Faktor-faktor yang dimaksud, antara lain strategi koping keluarga yang meliputi emotion focused coping, problem focused coping, dan religious coping strategy. Selain strategi koping keluarga, faktor lainnya adalah motivasi keluarga, dan pengetahuan keluarga, mengonsumsi obat secara teratur dan mengikuti berbagai aktivitas ringan yang positif dapat lebih cepat merangsang proses pemulihan. Dan hal tersebut dapat tercapai dengan dukungan keluarga, diharapkan keluarga dapat memahami tugas dan fungsinya serta bagaimana memberikan dukungan sosial bersedia 
menerima apa yang sedang dialami oleh pasien, (Yah Eni dan Yohanes Kartika Herdiyanto, 2018)

4. Dukungan afektif

Tabel 4. Dukungan afektif

\begin{tabular}{|c|c|c|c|c|c|c|}
\hline \multirow{3}{*}{ Umur } & \multicolumn{4}{|c|}{ Dukungan keluarga afektif } & \multirow{2}{*}{\multicolumn{2}{|c|}{ Total }} \\
\hline & \multicolumn{2}{|c|}{ Positif } & \multicolumn{2}{|c|}{ Negatif } & & \\
\hline & f & $\%$ & f & $\%$ & f & $\%$ \\
\hline $12-16$ th & 1 & $4 \%$ & 2 & $8 \%$ & 3 & $12 \%$ \\
\hline $17-25$ th & 3 & $12 \%$ & 6 & $24 \%$ & 9 & $36 \%$ \\
\hline $26-35$ th & 6 & $24 \%$ & 2 & $8 \%$ & 8 & $32 \%$ \\
\hline $36-45$ th & 2 & $8 \%$ & 1 & $4 \%$ & 3 & $12 \%$ \\
\hline $46-55$ th & 1 & $4 \%$ & 1 & $4 \%$ & 2 & $8 \%$ \\
\hline Total & 13 & $52 \%$ & 12 & $48 \%$ & 25 & $100 \%$ \\
\hline \multirow{2}{*}{ Jenis kelamin } & \multicolumn{2}{|c|}{ Positif } & \multicolumn{2}{|c|}{ Negatif } & \multicolumn{2}{|c|}{ Total } \\
\hline & $\mathbf{f}$ & $\%$ & f & $\%$ & $\mathbf{f}$ & $\%$ \\
\hline Laki-laki & 5 & $20 \%$ & 3 & $12 \%$ & 8 & $32 \%$ \\
\hline Perempuan & 8 & $32 \%$ & 9 & $38 \%$ & 17 & $68 \%$ \\
\hline Total & 13 & $52 \%$ & 12 & $48 \%$ & 25 & $100 \%$ \\
\hline \multirow{2}{*}{ Posisi dalam keluarga } & \multicolumn{2}{|c|}{ Positif } & \multicolumn{2}{|c|}{ Negatif } & \multicolumn{2}{|c|}{ Total } \\
\hline & $\mathbf{f}$ & $\%$ & $\mathbf{f}$ & $\%$ & $\mathbf{f}$ & $\%$ \\
\hline Ayah & 2 & $8 \%$ & 0 & $0 \%$ & 2 & $8 \%$ \\
\hline Ibu & 0 & $0 \%$ & 1 & $4 \%$ & 1 & $4 \%$ \\
\hline Kakak & 4 & $16 \%$ & 5 & $20 \%$ & 9 & $35 \%$ \\
\hline Adik & 1 & $4 \%$ & 2 & $8 \%$ & 3 & $12 \%$ \\
\hline $\begin{array}{c}\text { Lain-lain (sepupu tinggal } 1 \\
\text { rumah) }\end{array}$ & 6 & $24 \%$ & 4 & $16 \%$ & 10 & $40 \%$ \\
\hline Total & 13 & $52 \%$ & 12 & $48 \%$ & 25 & $100 \%$ \\
\hline \multirow{2}{*}{ Status } & \multicolumn{2}{|c|}{ Positif } & \multicolumn{2}{|c|}{ Negatif } & \multicolumn{2}{|c|}{ Total } \\
\hline & $\mathbf{f}$ & $\%$ & f & $\%$ & $\mathbf{f}$ & $\%$ \\
\hline Menikah & 9 & $36 \%$ & 5 & $20 \%$ & 14 & $56 \%$ \\
\hline Belum menikah & 4 & $16 \%$ & 7 & $28 \%$ & 11 & $44 \%$ \\
\hline Total & 13 & $52 \%$ & 12 & $48 \%$ & 25 & $100 \%$ \\
\hline \multirow{2}{*}{ Pekerjaan } & \multicolumn{2}{|c|}{ Positif } & \multicolumn{2}{|c|}{ Negatif } & \multicolumn{2}{|c|}{ Total } \\
\hline & $\mathbf{f}$ & $\%$ & f & $\%$ & f & $\%$ \\
\hline Tidak bekerja & 4 & $16 \%$ & 5 & $20 \%$ & 9 & $36 \%$ \\
\hline PNS & 4 & $16 \%$ & 2 & $8 \%$ & 6 & $24 \%$ \\
\hline Wiraswasta & 5 & $20 \%$ & 5 & $20 \%$ & 10 & $40 \%$ \\
\hline Total & 13 & $52 \%$ & 12 & $48 \%$ & 25 & $100 \%$ \\
\hline \multirow{2}{*}{ Keturunan } & \multicolumn{2}{|c|}{ Positif } & \multicolumn{2}{|c|}{ Negatif } & \multicolumn{2}{|c|}{ Total } \\
\hline & $\mathbf{f}$ & $\%$ & f & $\%$ & $f$ & $\%$ \\
\hline Ada & 11 & $44 \%$ & 9 & $36 \%$ & 20 & $80 \%$ \\
\hline Tidak & 2 & $8 \%$ & 3 & $12 \%$ & 5 & $20 \%$ \\
\hline Total & 13 & $52 \%$ & 12 & $48 \%$ & 25 & $100 \%$ \\
\hline
\end{tabular}

Sedikit berbeda dengan dukungan kognitif, pada dukungan afektif masih banyak yang 69| Wiraraja Medika memberikan dukungan negatif kepada pasien gangguan jiwa berusia 17 sampai 25 
tahun, dengan jenis kelamin perempuan dengan hubungan sebagai kakak dan sepupu dengan status belum menikah, bekerja sebagai wiraswata dan mempunyai Riwayat keluarga memiliki gangguan jiwa.

Perempuan lebih mengutamakan perasaan sehingga, dan pada penelitian ini masih cukup banyak yang memberikan dukungan negative meskipun hubungan kekeluargaan sebagai kakak.

Dukungan afektif dari keluarga pasien gangguan seperti menyediakan waktu dan fasilitas jika klien memerlukan untuk keperluan pengobatan. berperan aktif dalam setiap pengobatan dan perawatan sakit klien. mengingatkan, memberikan, dan memastikan pasien untuk minum obat $(\mathrm{PH}$ et al., 2018). mencintai dan memperhatikan keadaan klien selama klien sakit. memberi semangat pada klien memberikan fasilitas alat mandi, makan, yang diperlukan untuk aktivitas sehari-hari meluangkan waktu untuk menemani penderita agar tetap menjaga kesehatan, menyediakan transportasi untuk mempermudah dalam perawatan kesehatan, mengajak pasien untuk beraktifitas seperti membersihkan halaman rumah, menganjurkan pasien untuk mandi, membantu dan mendampingi aktifitas pasien selama pasien dirumah

Dukungan keluarga dapat mendukung Keberfungsian sosial dari orang dengan gangguan jiwa, dapat meningkatkan kemampuannya dalam melaksanakan tugas dan perannya selama berinteraksi pada lingkungan dan keluarganya. Kemampuan orang dengan gangguan jiwa sebagai anggota keluarga dalam berfungsi sosial secara positif dan adaptif dapat menggambarkan bagaimana fungsi keluarga seharusnya. tetapi, hal tersebut tidaklah mudah bagi orang dengan gangguan jwia memiliki hambatan dalam menjalankan peran sosial, sehingga memerlukan dukungan keluarga. Sebagai unit terkecil masyarakat terdekat dengan individu, keluarga dapat membantu merawat dan mengembangkan kemampuan anggota keluarganya.(Fauziah \& Latipun, 2016)

\section{KESIMPULAN}

Hasil penelitian menunjukkan bahwa lebih dari separuh keluarga telah memberikan dukungan yang positif. dukungan kognitif positif diberikan oleh keluarga dengan rentang usia terbanyak 17 sampai 25 tahun, lebih banyak berjenis kelamin perempuan dengan hubungan sebagai sepupu, sedangkan pada dukungan afektif masih banyak yang memberikan dukungan negatif kepada pasien gangguan jiwa, dengan berusia 17 sampai 25 tahun, dengan jenis kelamin perempuan dengan hubungan sebagai kakak dan sepupu dengan status belum menikah, bekerja sebagai wiraswata dan mempunyai Riwayat keluarga memiliki gangguan jiwa.. Diharapkan keluarga memberikan dukungan kepada orang dengan gangguan jiwa baik dukungan kognitif maupun dukungan afektif, dukungan keluarga dapat meningkatkan kemandirian serta kesembuhan orang dengan gangguan jiwa.

\section{DAFTAR PUSTAKA}

Choudhari, R. (2020). COVID 19 pandemic: Mental health challenges of internal migrant workers of India. Asian Journal of Psychiatry, 54(May), 102254. https://doi.org/10.1016/j.ajp.2020.10 2254

Fauziah, S., \& Latipun. (2016). Hubungan Dukungan Keluarga dan Keberfungsian Sosial pada Pasien Skizofrenia Rawat Jalan. Jurnal Ilmiah Psikologi Terapan, 04(02), 140-160.

Gani, A. (2019). DUKUNGAN KELUARGA TERHADAP KEKAMBUHAN PASIEN GANGGUAN JIWA DI RUMAH SAKIT JIWA PROF. Dr.SOEROYO DI MAGELANG. JPP (Jurnal Kesehatan Poltekkes Palembang), 14(1), 59-64. https://doi.org/10.36086/jpp.v14i1.3 99

Karmila, K., Lestari, D. R., \& Herawati, H. (2017). Dukungan Keluarga Dengan Kepatuhan Minum Obat Pada Pasien Gangguan Jiwa Di Wilayah Kerja Puskesmas Banjarbaru. Dunia Keperawatan, $\quad 4(2), \quad 88$. https://doi.org/10.20527/dk.v4i2.255 8

Khamida, K., Muhith, A., \& Safitri, R. D. (2018). DUKUNGAN KELUARGA DENGAN KEMANDIRIAN ORANG DENGAN GANGGUAN JIWA (ODGJ). WIRARAJA MEDIKA, 8(2). https://doi.org/10.24929/fik.v8i2.645

PH, L., Hermanto, H., \& Pratama, N. P. (2018). Dukungan Keluarga dengan Perawatan Diri pada Pasein Gangguan Jiwa di Poli Jiwa. Jurnal Kesehatan Manarang, 4(1), 
11.

https://doi.org/10.33490/jkm.v4i1.54

Rosdiana, R. (2018). Identifikasi Peran Keluarga Penderita dalam Upaya Penanganan Gangguan Jiwa Skizofrenia. Media Kesehatan Masyarakat Indonesia, 14(2), 174. https://doi.org/10.30597/mkmi.v14i2. 3787

Sanchaya, K. P., Made, N., Sulistiowati, D., Putu, N., Darma, E., Studi, P., Keperawatan, I., Kedokteran, F., Udayana, U., Jiwa, D. K., Studi, P., Keperawatan, I., Kedokteran, F., \& Udayana, U. (2018). HUBUNGAN DUKUNGAN KELUARGA DENGAN KUALITAS HIDUP ORANG DENGAN GANGGUAN JIWA. Jurnal Ilmu Keperawatan Jiwa, 1(2), 87-92.

Shalaby, R. A. H., \& Agyapong, V. I. O. (2020). Peer Support in Mental Health: Literature Review. JMIR Ment Health, $7(6)$, e15572. https://doi.org/10.2196/15572

Sierau, S., Schneider, E., Nesterko, Y., \& Glaesmer, H. (2019). Alone, but protected? Effects of social support on mental health of unaccompanied refugee minors. European Child \& Adolescent Psychiatry, 28(6), 769-780. https://doi.org/10.1007/s00787-0181246-5

Suprayitno, E., Rahmawati, S., Ragayasa, A.,
\& Pratama, M. Y. (2020). Pengetahuan dan Sikap Masyarakat dalam Pencegahan COVID-19. Journal of Health Science (Jurnal Ilmu Kesehatan), 5(2), 68-73.

Syafitri, A. (2015). Pengaruh tingkat dukungan sosial keluarga terhadap tingkat kecemasan menjelang pensiun pada karyawan perusahaan $\mathrm{X}$ di kecamatan Kebomas kabupaten Gresik. Psikosains, 1O(1), 2015.

Vest, B. M., Cercone Heavey, S., Homish, D. L., \& Homish, G. G. (2017). Marital Satisfaction, Family Support, and PreDeployment Resiliency Factors Related to Mental Health Outcomes for Reserve and National Guard Soldiers. Military Behavioral Health, 5(4), 313-323. https://doi.org/10.1080/21635781.20 17.1343694

Yah Eni dan Yohanes Kartika Herdiyanto, K. (2018). Dukungan Sosial Keluarga terhadap Pemulihan Orang dengan Skizofrenia (ODS) di Bali. Jurnal Psikologi Udayana, 5(2), 268-281.

Yusuf, A., Tristiana, R. D., Purwo, I., \& Keperawatan, F. (2017). Fenomena Pasung dan Dukungan Keluarga terhadap Pasien Gangguan Jiwa Pasca Pasung. In JKP (Vol. 5). 